\title{
The 2011 ACR Meeting: what's new in the Windy City
}

David S Pisetsky*

Among the many things I learned at the American College of Rheumatology (ACR) meeting in Chicago this year is the answer to the question, 'Which medical advance was developed in Chicago?' This nugget of information was not the product of a lecture or poster session. Rather, it was flashed on the computer screen in the shuttle bus that transported me every day from the Palmer House on Monroe Street to the McCormick Place convention center. The convention center is gargantuan and is clearly vying for designation as one of the wonders of the modern world. Alas, the territory near the center is barren and only a Hyatt Regent hotel sits forlornly at the site, anxiously awaiting some company from brethren named Sheraton, Hilton or Ritz-Carlton.

Each day, the shuttle bus brought people from the downtown hotels from around the Loop and Gold Coast, through obstacles that included the snarl of traffic, curtains of driving rain, and a road race in which seemingly every inhabitant of the state of Illinois put on his Nike shoes to run for the glory. To keep bus passengers bemused and serene during these sometimes tedious commutes, a computer system thoughtfully presented a series of questions about Chicago as divertissements and a few seconds later flashed the answers. The only medical question concerned the advance hatched in the confines of the Windy City. The choices were stethoscope, X-rays, kidney transplants and blood bank.

The correct answer is blood bank.

Before my trip, I was totally unaware of this fact and was glad to learn it along with the first animal purchased for the Chicago zoo, the name of the cookie factory located in the city and the amusement park attraction that debuted on the banks of Lake Michigan. This information is permanently instilled in the memory banks of my brain since I had about a dozen round trips to the convention center and the questions and answers were repeated non-stop. Alas, this knowledge will not change my practice and I did not detect any commercial

*Correspondence: dpiset@acpub.duke.edu

Duke University Medical Center, 151G, Durham VAMC, Durham, NC 27705, USA bias beyond some boosterism on the part of the city fathers and mothers to tout the history of a city the American poet Carl Sandburg called stormy, husky and brawling, not exactly attributes of most rheumatologists.

Once off the bus at the convention center, the opportunity for real knowledge was staggering given the cornucopia of symposia, lectures and poster presentations. In a room that seemed bigger than the stockyards that made Chicago the hog butcher of the world, hundreds of bright eyed and bushy-tailed young investigators stood expectantly by their posters, eager to tell the story of their travails in the lab or in a data bank. Who knew there was so much new research? In contrast to the ACR meetings of the past that were communal affairs held in a single hotel, today's meeting can convene in the very few cities that have enough hotel rooms for the thousands of attendees. Nevertheless, despite the throngs of people, today's meetings are very impersonal, even isolating, as attendees race, charge and bound from room to room, diligently following a schedule that they have designed to get their own unique smattering of CME (Continuing Medical Education) goodies.

Since I am a researcher who spends his time doing science and reviewing for journals like Arthritis Research $\mathcal{E}$ Therapy, I use the ACR meeting to get updates on clinical subjects, especially unusual conditions I have seen on our consult service. Rheumatology is a strange subspecialty since, within its purview, are a large collection of virtually unrelated conditions that, for some arcane reasons, have been designated as 'rheumatological' and hence require subspecialty expertise. The difficulty with this situation, of course, is that many of these conditions are quite rare and defy the acquisition of expertise. Nevertheless, the good rheumatologist, when asked to see a mysterious case that has eluded or befuddled other specialists, has to be ready to opine on amyloidosis, X-linked hypophosphatemic rickets or McArdle's syndrome.

Thus, this year, I went to lectures on hereditary angioedema, pyoderma gangrenosum and hypereosinophilic syndrome. Among things I learned was to think $\mathrm{W}$ when confronted with a patient with too many eos. The W refers to worms, wheezes and weirdness. The weirdness 
category is perfect for rheumatologists and includes Churg-Strauss syndrome, cholesterol emboli and NSAIDs. Not to overdo the obscure, I also attended lectures on lupus nephritis and the management of anti-phospholipid antibody syndrome. The lupus session was especially popular and completely filled a cavernous hall. To hear the talks, I had to sit on the floor in one of the spacious lobbies, watching on a big screen TV that glowed brightly while the voice of a disembodied lecturer emanated scratchily from a sound system. Bottom line. When it comes to lupus, hard data are still lacking and people do many different things when confronted with ominous rises in the creatinine or the urinary protein. Whether lupus will ever have a class IA study for evidence-based practice remains to be seen.

Another interesting session that I attended concerned muscle disease. While inflammatory myopathy is relatively rare, concerns about muscle disease are skyrocketing related primarily to the widespread use of statins, which can bedevil the musculature in a variety of ways. Something like $10 \%$ of the adult population is taking a statin and, as the goal for cholesterol control becomes more ambitious, that number can only increase. On the radio the other day, I heard a story about cholesterol screening for children perhaps triggered by fears of what a diet of Big Macs and Whoppers can do. While many children will outgrow their elevated cholesterol levels, some public health advocates are suggesting statin treatment to get a jump on the accelerated atherosclerosis that bad lipids can promote. I can see the new happy meal: a cheese burger and a side of Lipitor.

While myalgias and cramps are frequent among statin users, some patients may develop an inflammatory myopathy or inclusion body myositis. Given the frequency of statin use, such occurrence may coincidence. Some patients, however, present with a newly recognized form of myopathy that appears to be genuinely associated with statin use and has a fascinating serological profile that may provide a clue to etiology. Thus, as described in a lecture from Dr Lisa Christopher-Stine from Johns Hopkins, statin users are prone to immune-mediated necrotizing myopathy (IMMS) that has a distinct set of clinical and histopathological findings. This condition presents with widespread muscle pain and weakness, with biopsies showing evidence of myocyte necrosis.

Intriguingly, patients with IMMS express antibodies to the target of statin action, the enzyme 3-hydroxy-3methylglutaryl coenzyme A reductase (HMGCR). This serological feature was defined originally by Western blots showing antibodies to proteins with molecular weights of $100 \mathrm{kDa}$ and $200 \mathrm{kDa}$; molecular techniques established the identity of the $100 \mathrm{kDa}$ protein as HMGCR; the $200 \mathrm{kDa}$ band may result from a dimer or associated protein. The link between antibodies to HMGCR and statin use suggests a scenario in which statin use decreases cholesterol levels, which in turn induces HMGCR production. This up-regulation somehow may increase immunogenicity and drive the production of autoantibodies that may damage myocytes. Furthermore, since regenerating muscle can also show HMGCR upregulation, a repair response to an initial injury may exacerbate autoimmunity, fueling the fire with an ever increasing supply of autoantigen to stimulate pathogenic $\mathrm{B}$ and $\mathrm{T}$ cell responses.

This model, while attractive and consistent with the data, may be insufficient to explain an anti-HMGCR response since it suggests that the immune system is exquisitely sensitive to even small changes in the expression levels of protein. Other mechanisms may therefore be at play. Thus, binding of a statin to the enzyme could create structural change that alters the enzyme's conformation or intracellular metabolism to promote autoimmunization. Perhaps muscle has an unusual sensitivity to the effects of cholesterol and is predisposed to injury as the cholesterol levels drop.

The single session on muscle disease had an abundance of food for thought. Indeed, it was a veritable banquet or smorgasbord with a profusion of tasty dishes for the intellect. Dr Dana Ascherman from the University of Miami reviewed potential biomarkers for myositis, discussing both autoantibodies and markers of immune cell dysfunction present in patients with myositis. These muscle-specific antibodies have curious clinical associations, such as interstitial lung disease, skin findings and vasculitis, with their origin reflecting perturbations of the innate immune systems that may involve molecules like MDA5 (melanoma differentiation gene 5), a target of autoreactity. MDA5 is a cytoplasmic sensor for RNA that may be key for the innate immune response to viral infection. Could each of these muscle-specific antibodies result from some type of environmental insult just as anti-HMGCR results from statin exposure?

The implications of these findings are wide ranging and extend from public health to detailed cell and molecular biology. On the clinical side are questions like the following: is IMMS the tip of the iceberg of statin-induced muscle disease - the canary in the mine shaft - that should suggest caution in the extent of their use? Should patients be screened for the antibodies as a strategy to reduce the likelihood of IMMS? How can environmental triggers for autoimmunity be found if the risk is so low? Then there is the question of how statins, a class of agent with potential immunosuppressive activity, including modulation of $\mathrm{T}$ regulatory cells, promote autoimmunity at the same time as they dampen other responses.

I was surprisingly attentive at the meeting. I also learned about the role of $\beta$-catenin in the pathogenesis of scleroderma, the treatment of erythema nodosum and 
the side effects of dapsone. I also learned the name of the first person who ever stayed at the Palmer House. That piece of information was provided by the computer screen in the elevator in my hotel. In Chicago, new knowledge was everywhere and not just at the convention center.

For those of you curious about the first animal purchased for the zoo or the amusement park ride that originated in Chicago, I suggest you do what my fellows do when I ask them the differential of hypereosinophilia. They look on Google. While, in medicine, we call this approach practice-based learning, the rest of the world calls it surfing the web. Go for it. Surf's up and see you at the 2012 ACR meeting in Washington.

\section{Abbreviations}

ACR, American College of Rheumatology; HMGCR, 3-hydroxy-3-methylglutaryl coenzyme A reductase; IMMS, immune-mediated necrotizing myopathy;

NSAID, non-steroidal anti-inflammatory drug.

Published: 21 December 2011

\section{References}

Christopher-Stine L, Casciola-Rosen LA, Hong G, Chung T, Corse AM, Mammen AL: A novel autoantibody recognizing $200-\mathrm{kd}$ and $100-\mathrm{kd}$ proteins is associated with an immune-mediated necrotizing myopathy. Arthritis Rheum 2010, 62:2757-2766.
Fiorentino D, Chung L, Zwerner J, Rosen A, Casciola-Rosen L: The mucocutaneous and systemic phenotype of dermatomyositis patients with antibodies to MDA5 (CADM-140): a retrospective study. J Am Acad Dermatol 2011, 65:25-34.

Kim YC, Kim KK, Shevach EM: Simvastatin induces Foxp3+ T regulatory cells by modulation of transforming growth factor-beta signal transduction. Immunology 2010, 130:484-493.

Mammen AL: Autoimmune myopathies: autoantibodies, phenotypes and pathogenesis. Nat Rev 2011, 7:343-354.

Mammen AL, Chung T, Christopher-Stine L, Rosen P, Rosen A, Doering KR, CasciolaRosen LA: Autoantibodies against 3-hydroxy-3-methylglutaryl-coenzyme A reductase in patients with statin-associated autoimmune myopathy. Arthritis Rheum 2011, 63:713-721.

Roufosse F, Weller PF: Practical approach to the patient with hypereosinophilia. J Allergy Clin Immunol 2010, 126:39-44.

Saketkoo LA, Ascherman DP, Cottin V, Christopher-Stine L, Danoff SK, Oddis CV: Interstitial lung disease in idiopathic inflammatory myopathy. Curr Rheumatol Rev 2010, 6:108-119.

Sato S, Hoshino K, Satoh T, Fujita T, Kawakami Y, Fujita T, Kuwana M: RNA helicase encoded by melanoma differentiation-associated gene 5 is a major autoantigen in patients with clinically amyopathic dermatomyositis. Arthritis Rheum 2009, 60:2193-2200.

doi:10.1186/ar3532

Cite this article as: Pisetsky DS: The 2011 ACR Meeting: what's new in the

Windy City. Arthritis Research \& Therapy 2011, 13:138. 